\title{
ПОАІЯ В ІСТОРІЇ МИСТЕЦТВА: ВИРОБНИЦТВО СТАТУСУ
}

\author{
O^EKCAHAP KАEKOBKIH
}

\begin{abstract}
Анотація. Загальна історія, історія виконавського мистецтва, як і театральна режисура, збігаються в одному зі своїх завдань: створенні icmoріï (вигаданої або правдивої), виробництві події засобами своєї науки або мистецтва з опорою на історичні джерела у науковців або на текст драми - у режисера. Це означає, що дослідницькі методи загальної історії, як і методи режисерського аналізу, можуть бути запозичені історією перформативного мистецтва, тим більше що кмючові поняття, на які спираються названі галузі - факт і подія, - збігаються. У Аискусіях з приводу природи наукового факту можна виокремити кілька найголовніших підходів, сереА яких: факт - це повідомлення якогось Ажерела, свідка і т. ін.; факт - це те, що сталося насправАi; науковий факт - це конструкт, створений досліАником у результаті аналізу, зіставлення й узагальнення одиничних елементарних фактів, слідів якоїсь події. Ще більше розбіжностей існує у визначенні поняття подія. Недостатня чіткість у визначенні цих і деяких інших пов'язаних з ними понять зумовлює інколи несвідому маніпуляцію - підміну фактів - історичними свідченнями, подій - фактами, зокрема фактами культовими, медійними, що призводить, зрештою, до Аомінування в історії мистецтва суб'єктивного, релігійного або ж іАеологічного чинника. На численних приклаАах з історії світового й українського театру виявмено зразки історії, написаної всупереч фактам (коли ігнорування віАмінностей між свіАченнями і різними статусами факту факт, подія, реліквія, прецедент тощо - призводить до створення історичних міфів, панування яких зумовлено, зокрема, імперськими впливами), і продемонстровано можливості застосування методу Аійового аналізу в історії театру. Розгляд історії перформативного мистецтва піА кутом зору подієвої історії створює передумови Аля зміни порядку денного і розширення рубрик переліку запитань, віАповіАі на які мусять збагатити не мише мистецтвознавство, а й мистецьку практику, знання не лише про минуме театру, а й про його сучасний стан.

Ключові слова: Факт - статус факту (елементарний, медійний, прихований, прагматичний, культурний) - подія - явище - реліквія.
\end{abstract}

Постановка пробмеми. Пропоновану розвіАку присвячено пробцемі методології сучасного театрознавчого, а у широкому сенсі мистецтвознавчого Аослідження, місцю факту в ньому, а також створення на його основі історичної події.

Незважаючи на те що у загальній історії подієва (наративна) історія давно перебуває під критикою, а подеколи сприймається навіть як учорашній Аень, в історії мистецтва, принаймні в історії мистецтва виконавського, і досі домі- нує, імітуючи подієву історію, історія описова, а посутньо - культова.

Загальна історія, історія виконавського мистецтва, як і театральна режисура, збігаються в оАному зі своїх завдань: створенні історії (вигаданої або правдивої), виробництві подї засобами своєї науки або мистецтва, з опорою на історичні Ажерела у науковців або на текст Арами - у режисера; отже, АосліАницькі метоАи загальної історії, як і метоАи режисерського аналізу, можуть бути запозичені історіогра- 
фією перформативного мистецтва, тим більше, що кАючові поняття, на які спираються названі галузі - факт і подія, - збігаються.

У Аискусіях із приводу природи наукового факту можна виокремити кілька найголовніших піАходів, сереА яких: фбакт - це повідомлення якогось Ажерела, свіАка і т. ін.; фбакт це те, що сталося насправАі; науковий бакт це конструкт, створений АосліАником у резумьтаті аналізу, зістав ення й узагацьнення одиничних елементарних фактів, слідів якоїсь події. Ще більше розбіжностей існує у визначенні поняття подія.

Недостатня чіткість у визначенні цих і деяких інших пов'язаних з ними понять зумовАює підміну фактів - історичними свідченнями, поАій фактами, зокрема фактами культовими, медійними, що призводить, зрештою, Ао Аомінування в історії мистецтва суб’єктивного, релігійного або ж ідеологічного чинника, що за впливом на свідомість можна порівняти із 25-м кадром.

На численних прикладах з історії світового й українського театру може бути виявлено зразки історії, написаної всупереч фактам (коли ігнорування відмінностей між свідченнями, фактами і подіями призводить Ао створення історичних міфів, панування яких зумовлено, зокрема, імперськими впливами), і продемонстровано можмивості застосування дійового аналізу в історії театру.

Подієва історія театру і мистецтва створює, у свою чергу, переАумови Аля зміни поряАку Аенного і розширення рубрик - переліку запитань, відповіді на які мусять збагатити не Аише мистецтвознавство, а й мистецьку практику.

Аналіз останніх досліджень і публікацій. Методологія театрознавчого АосліАжен-

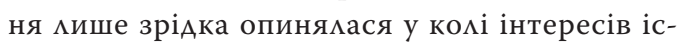
ториків театру; подієва історія, як оАин із напрямів дослідження мистецтва, Аосі взага$\Lambda$ не потрапляма у центр їхньої уваги. Разом із тим, у соціології, загальній історії, культурології й особливо у практиці режисури накопичено Аостатній АосвіА Аійового/подієвого аналізу, що може бути використано у мистецтвознавчих Аослідженнях. Концепція досліАження базується на іАеях, запропонованих соціологією (М. Вебер, М. Карєєв, П. БурАьє), театрознавством (Я. Мамонтов), історіографі$\epsilon ю(\Lambda$. Ранке, М. Блок, А. Февр, П. Вен, Г. Вайт), культурологією (П. Берк, Ю. Аотман), філософією ( $\Lambda$. Вітгенштайн, Р. Рорті), епістемологі$є ю$ (К. Поппер, $\Lambda$. Фмек, М. Фуко), практиками сцени (К. Станіславський, М. Кнебель, Г. Товстоногов, П. Єршов, О. Поламішев) та іншими галузями знань.

Метою статті $€$ Аиференціювання кцючових понять подієвої історії (факт - подія - явище - реліквія - рубрика та ін.) і окреслення можиивостей їхнього застосування у мистецтвознавстві.

ВикмаА основного матеріаку. Завданням історії мистецтва інколи вважають виклаА історичних «фактів» у послідовному, психологічно, соціально, економічно і культурно мотивованому казуальному зв'язку в межах запропонованих історією обставин, тобто у межах ідеологічних Аоктрин доби. Такий Аоволі широкий спосіб розповіАі про минуме Аістав назву наративної, подієвої або описової історії. $\mathrm{O}_{A}-$ нак скроєна «з миру по нитці», без критичного аналізу Ажерел, у найбанальніших своїх зразках подібна історія мистецтва перетворюється на суміш фактів із життя видатного митця та його оточення й «естетичної критики» видатних творів на тлі історичних подій, тобто ілюстрації до іАеологічно забарвлених уявмень про минуле. Недарма Робін Ажорж КоАінгвуд називав таку історію наукою ножиць $i$ клею («Це $є$ те, що я називаю методом “ножиць і кцею”, себто компікятивним історичним метоАом» $[13$, с. 88]). Аеякі інші історики висловлювацися стриманіше, хоча посутньо махи на увазі те саме, коли казали, що, мовцяв, не настав ще час писати синтетичну історію, Аля якої неАостатньо накопичено перевірених фактів і т. ін. ОАнак перевірених ффактів ніколи й не буде накопичено Аостатньо. 
Поворотною у критиці наративної історії стала праця Гайдена Вайта, котрий завдав їй, сказали 6 у піАручнику Аля молоАших киасів, нищівного удару і розвінчав - зАавалося, остаточно; вона, мовАяв, зводиться Аише Ао того, щоб вигадувати цікавий сюжет i, з урахуванням жанру, розташовувати в ньому достеменні, а подеколи і гіпотетичні події. ААже наративна форма, писав Вайт, передбачає «надання “сенсу" історії на основі встановлення типу розповіАі, тобто пояснення за допомогою побудови сюжету. <..> Мішле виконав усі свої історії як Роман, Ранке - як Комедію, Токвіль - як ТрагеАію, а БуркгарАт використовував Сатиру» [20, c. 76]. Але таких «історій», пише Вайт, не так уже й багато: це «антикварна», «монументацьна» й «критична» історія у визначенні ФріАріха Ніцше; «драма тріумфу добра наА змом, чеснот наА пороком, світла наА темрявою і фінальний вихіА мюАини за межі світу»; «Арама приреченості»; «романтична історія»; «біографічна», «катастрофічна» історія тощо [20, с. 28, 69, $91,315]$. ОАнак, якщо згаАати і взяти на віру висновки Жоржа Помьті про те, що у Араматургії існує Аише триАцять шість сюжетів, тобто моАелей розвитку, АовеАеться погоАитися із тим, що і в нашому розумінні минулого існує також не більше цієї кількості історій. ЩоправАа, автори, схимьні Ао більших узагальнень, вважають, що таких історій набагато менше.

Зрозуміко, що сюжет - завжАи залежний віА міфу, повсякчас він базується на архетипі і не може бути позаідеологічним. ОАнак чи цим тільки зумовлено критику подієвої історії? Чи не зумовцено її іншою, також «технологічною» причиною - неАостатньою чіткістю у визначенні кцючових понять наративної, та й не тільки, історії - факту, обставин, nодї, явища? На цю проблему звертали увагу не $и$ іс історики театру, а й практики сцени: «Питання розкриття події $\epsilon$ на сьогодні карАинальним Аля сучасного мистецтва. ВіА того, як ми будемо ставитися наАаАі Ао цього питання, залежить куди буде розвиватися мистец- тво театру» [10, с. 59]. I не тікьки театру. ААже проблема визначення історичного факту і поАії Аавно постала і перед істориками: приміром, М. Барг розрізняв події моментальні, ииклічні (періодичні) і подї більшої або меншої тривалості (циклічні процеси) [1, с. 154-155].

Історія театру, якщо вона прагне бути наукою, не виняток із цього правика, яке розуміки українські АосліАники театру ще у 1920-1930-х роках. Це гарно ілюструє мимовільна рецензія Якова Мамонтова на працю Олександра Кисіля: «Ав-

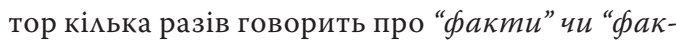
тичний матеріал”, що становить нібито основний зміст його роботи. По таких заявах читач сподівається, що в О. Кисіля буде максимум ффактичних даних 3 нашого театрального минулого і мінімум суб'єктивних оцінок, що виникають з особистих уподобань автора, а не з "фактичних матеріалів”. На жаль, автор не дотримав навіть цього принципу й начинив свій виклаА силою суб'єктивних або традиційних (за істориками Аітератури) вироків щодо окремих компонентів театру, а найбільш - щодо Араматургів та окремих п'єс. Ось, наприкцаА, про I. Тобімевича говориться, що його твори - найкращі в нашому побутовому репертуарі, що в творах тих композиція - струнка та ясна, образи яскраві, мова - прекрасна. А де ж ті “факти” чи "матеріали", що Аогічно приводики б автора Ао таких висновків? Перечитайте все, од слова Ао слова, що говорить О. Кисіль про Араматургію І. Тобімевича і жадних підстав Аля таких висновків ви не побачите: ні про композицію п'єс I. Тобілевича, ні про його Аіалог, ні про його засоби щодо подачі персонажів О. Кисіль нічогісінько не говорить, а висновок (отой шумьмейстерський “бал”) робить - так би мовити в інтуїтивний спосіб. I так - на кожному кроці “Українського театру”. Це - абсолютно неприпустима річ ані в наукових, ані в популярних викладах. Зміст п'єси (тематичний, іАеологічний) та Аітературна характеристика типажу ще нічого не говорять за композицію п'єси та Араматургічну майстерність їі автора. Отже, гово- 
рячи про “бузину”, робити висновки про “АяАька” історикові театра не годиться навіть в Аонауковій фазі його» [16, с. 149]. ПоАібні зауваження висуває Мамонтов і на адресу Петра Руліна: «Свою методу П. Рулін найвиразніше продемонстрував у розвідці про “Життя і творчість М. Кропивницького”. Не муара ця метоАа: за хронологічним поряАком переказуються зміст окремих п'єс Кропивницького, характеризуються типажі і робляться деякі зауваження щодо Араматичного жанру. Цим і вичерпуються анаціза творчості Кропивницького» [16, c. 150]. Присуд Мамонтова не в усьому справеАмивий (аАже О. Кисіль писав «популярний нарис з історії українського театру», а не «наукове Аослідження»), і його не варто було би розлого цитувати, якби він стосувався Аише Кисіля та його Аоби. ОАнак у спостереженні Мамонтова виявлено, як зневага до факту веде до регресу наукової історії театру, тобто переходу іiі на нижчу на еволюційному рівні сходинку.

Проблемою визначення (або відтворення) факту, обставин $i$ подій переймається сьогоАні не $и$ ше історична наука і криміналістика, а й театральна режисура, котра також накопичила значний АосвіА аналізу цих понять. На жаль, оАнак, Аосвіди різних форм Аіяльності існують зазвичай у паралельних світах і жоАним чином не перетинаються, хоча досвіА загальної історії міг би збагатити практиків сцени і мистецтвознавців, а АосвіА практиків сцени - принаймні досліАників театру. ААже всіх їх об'єАнує завАання реконструкиії події: політичної - для дослідників політичної історії, мистецької-для мистецтвознавців та істориків театру, драматичної-для практиків сиени. Аеякі історики, як Гайден Вайт, узагалі мислять історію у поняттях киасичної теорії драми («жанр», «зав'язка», «розв’язка» [20, с. 2526]), описуючи тридімьний шлях віА тези й антитези Ао синтезу, віА зАету Ао занепаАу Аос $і$ Ажуваного явища у термінах Арістотекя, Фрайтага й авторів поетик шкільної Арами. Про таку саму тенденцію сприйняття історії як історич- ного перформансу пише і Г.-Т. Аеманн: «Вемика французька революція, з її грандіозними виходами на сцену, промовами, жестами і віАхоАами, знову і знову розглядалася як Арама $з$ їі власним конфліктом, розв'язкою, героїчними ролями і глядачами. ОАнак сприйняття історії як Арами майже неминуче вводить в гру телеомогію, в рамках якої ця Арама вказує на осмисмену перспективу: в ідеалістичної естетики такою буде примирення, а в марксистській історіографії - історичний прогрес» [14, с. 64]).

Отже, завдання історика перформансу байдуже, чи це буде перформанс помітичний, чи мистецький, або те й інше оАночасно, - peконструювати видовище, звісно не візуацьно, цим нехай займаються майстри батального або жанрового живопису. I результат реконструкції значною мірою залежатиме віА способу, яким визначатимуться і роз'єАнуватимуться пропоновані обставини, бакти, події, явища і медійні сплески навколо них, тобто маніпуляuіï. Особливо гостро проблема такої Аиференціації стоїть у сферах, де не завжАи можна чітко оцінити «економічний ефект» події, а причини народження того або іншого твору 一 й поготів. Що й створює передумови ААя маніпукювання, зазвичай з іАеологічним присмаком.

ОприлюАнення мистецького твору, виконання вистави або музичного твору, циркового номеру або перформансу стає фбактом мистецького життя за наявності комунікативной ситуацї, в якій безпосередню участь беруть виконавці і глядачі (слухачі), а опосередковано - й інші мистецькі колективи (конкуренти) та інституції (владні структури, засоби масової інформації тощо). ОАнак подією, з точки зору теорії Ара-

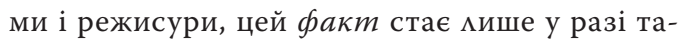
кого порушення рівноваги (звичних норм, конвенцій, бар'єрів, забобонів), котре спричинює істотні зміни в етичній, естетичній, політичній або будь-якій іншій площині; це може бути винахід, відкриття, за умови, що вони веАуть Ао змін у якійсь сфері життя, Аамають чинні конвенції, створюють «розширення» (у макмюенів- 
ському сенсі). У межах, визначених методом Аiйового аналізу, що був запропонований К. Станіславським, це «несподіваний приїзА Чацького» («Аихо з розуму» О. ГрибоєАова) [11, с. 316], «самогубство Катерини» («Гроза» О. Островського) [11, с. 413], «смерть батька» («Три сестри» А. Чехова) [19, с. 171], «пожежа» («Три сестри» А. Чехова) [19, с. 186], «Ауель Тузенбаха» («Три сестри» А. Чехова) [19, с. 188], «нова подія Аля Ромео: Ажульєтта - Аочка ворога» («Ромео і Ажульєтта» В. Шекспіра) [12, с. 24], «приїза ревізора» («Ревізор» М. Гоголя) [12, с. 26], «трагеАія Гамлета починається ще за межами п’єси, з її вихіАної події - смерті короля» («Гамлет» В. Шекспіра) [11, с. 302] та ін. Оцінити факти і події п'єси - «означає знайти в них прихований сенс, Ауховну сутність, ступінь їхнього значення $i$ виливу. Це означає підкопатися піА зовнішні факти і події, знайти там, в глибині, піА ними, іншу, більш важливу, глибоко приховану душевну подію, котра, можмиво, породи$\Lambda$ а сам зовнішній факт. Це означає простежити <...> напрям і Аінію прагнень кожної з Аійових осіб, пізнати махюнок багатьох внутрішніх $\Lambda$ iній Аійових осіб, їхні душевні зіткнення, перетини, сплетення, сходження і розбіжності при загальному прагненні кожного Ао своєї життєвої мети» $[17$, с. 93]. В іншій системі - системі понять, запропонованих Юрієм Аотманом, це означає пізнати рух, вибух $i$ взаємозв'язок між ними: «Рух упереА зАійснюється Авома шияхами. Наші органи почуттів реагують на невеАикі порції подразнень, які на рівні свідомості сприймаються як якийсь безперервний рух. У цьому сенсі безперервність - це осмислена передбачуваність. Антитезою їй є непередбачуваність, зміна, шо реалізовується в порядку вибуху. ПереАбачуваний розвиток на цьому тАі виАається значно менш суттєвою формою руху. <...> Поступові і вибухові процеси, преАстав яючи собою антитезу, існують тільки у віАношенні оАИн АО оАного. Знищення оАного полюса призвело би Ао зникнення іншого» $[15$, с. 17].
У разі, коли оприкюАнення (виконання) твору було спрямовано на зміни, однак автори

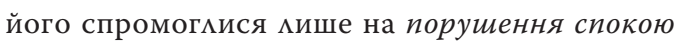
і на те, щоб кише сколихнуки кукьтурне сереАовище (політичне життя тощо), маємо справу з бактом бунту, заколоту або атракціоном. Медійну природу подібних фактів викривають синоніми: колотнеча, шум, галас, метушня, сум'яття, скандал, галаслива сварка, резонансний факт. Ао таких фбактів відносяться вчинки, які мають на меті привернення уваги Ао себе, а не розв'язання проблеми, котра має суспільне значення - різноманітні троллінги, ефектні жести, наслідування моди, спекуляції на екзотиці та інші борми імітації поdii. ХАопчик, який зчинив галас з приводу гомого короля, створив поки що меАійний привіА. Якби ж унаслідок зАійсненого ним оголення факту відбулося повакення короля, це означамо би, що скандал спровокував подію. РозгляА мистецького явища із точки зору запропонованої Аотманом Аіалекттичної пари (вибух рух) оголює також «проблему Аостеменного вибуху та імітації вибуху як форми антивибухової структури» [15, с. 19].

ОАнак події не розгортаються у вакуумі вони виростають із різних кік пропонованих обставин, зіставцяючи які ми наближаємося до розуміння змісту того або іншого фбакту або подіï. Приміром, наАзвичайно приємні Аля національної свідомості повіАомлення учасників і свіАків про виступ корифеїв українського театру на петербурзькій сцені зазвичай сприймаються як знак якості, визнання і найвищої мистецької оцінки. Ці повідомлення справцяють враження факmy, Аоки мінивий мозок несподівано не прокиАається і не ставить кілька запитань: віАколи смак політичної вцаАи став критерієм естетичної оцінки? відтоді як заборонив Шевченкові «писати й малювати»? і на кого було розраховано цей помітичний жест? і чи не був цей жест палацовим ритуалом? ВіАповісти на ці питання - це й означає «зіставити і проаналізувати запропоновані обставини». 
На перший погмяА, медійний бакт істотно віАрізняється віА події, аАже справляє враження, що бере участь мише у позиційній, а не у Аімовій боротьбі («наступ у боротьбі за взаємини називатимемо позиційним, на віАміну віА усіх інших випадків наступу й оборони, котрі можна називати (звісно, умовно) діловими. БуАь-який позиційний наступ розвивається у бік усе більших і більших узагальнень, він спрямований у протицежний віА Аілового змісту боротьби бік; він “уводить” учасників конфлікту від конкретних справ, від преАметної матеріальності цімей» [7, с. 97]). ОАнак насправді взаємини (сmamyc!) Ауже часто, особливо у мистецтві, є скмаАовою або етапом у боротьбі діковій.

Поряд зі згаданими типами фбактів і подій, котрі завжАи мають пубцічний характер, існують факти приховані, значення яких розкривається $\Lambda$ ише з бігом часу, адже не завжди фбакт має поАієву природу. Приміром, значення змови, таємної угоди, домовленості або таємного

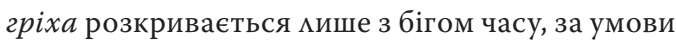
реалізації або принаймні оприлюднення змісту таємниці; саме в момент оприлюАнення, маніфестації фбакт може стати подією, культовим бактом, спричинити скандац, зумовити суспільні зміни тощо. Так, ні віАкриття Америки Колумбом, ні винахіА кінематографа в момент, коли вони відбулися, нічого не змінили у світі, їхнє значення розкрилося із затримкою, з бігом часу. Так само перші публічні покази вистав за п'єсами, котрі згодом було канонізовано і зараховано Ао киасики («Гамлет», «Натацка Помтавка» тощо), не стали подіями, аАже свого часу нічого не змінили у культурному житті, їхній вплив поширювався поступово, із затримкою, 3 кожним десятиліттям ставлення Ао цих творів як Ао раритетів, святинь, реліквій, культових пам'яток зростало. ОАнак збільшення впливу відбувалося не стихійно, аАже культ Шекспіра, як і будь-якого іншого митця, створювався цімеспрямовано: ювілеями, фестивалями та іншими формами вшанування, релігійного поклоніння i, таким чином, формування традиціі. Те саме стосується пам'ятних дат в історії українського театру, Аовкола яких упродовж стоАіття точаться Аискусії: 1591 рік («Просфонима», перша згаАка про вертеп в Е. Ізопольського), 1619 рік (інтермедія Я. Гаватовича) та ін. Це були одиничні факти, жоден із яких не змінив театральної культури, оАнак закмав піАвацини Ао культурної традицї - нового звичаю, потреби, системи культурних ритуалів і борм громадського спілкування. Факт поклоніння не означає, що канонізоване явище й справАі було подією. Подія віАрізняється віА канонізованого прецеденту як факт прагматичний віА факту культурного. Коли ж в історії прецеАентів з'являється теократична скмадова, а їі Аiйових осіб починають сприймати як богів, героїв, месій і святих мучеників, історичний викмаА стає квазісторичним або релігійним, в якому статус освячених релігійних фбактів Аістають визначення на кшталт «батько театру», «праматір українського театру» (К. Ванченко уїА иво згаАує про «"батька” української сцени М. $\Lambda$. Кропивницького, “маму” - М. К. Заньковецьку, “Аядьків” - Садовського й Карпенко-Карого та інш. близьких родичів» [5, с. 227]). Цей тип історії Ніцше називав монументалістським або антикварним, отже, і факти подібного гатунку сліА віАнести до антикваріату. ОАнак, саме як факти свіАомості, ці «монументи» Аопомагають зрозуміти особливості театральної кумьтури, котра запроваджує подібні формули.

СереА інших фактів, Ао яких унаслідок піАвищеного попиту впродовж тривацого часу прикуто увагу, вирізняються ті, характеристики яких визначаються досконалістю об'єкта споживання або модою, тобто факт перетворюється на взірець, еталон; ці факти реструктурують систему статусів, рейтингів і авторитетів (на кшталт такої ієрархії: «великий французький письменник ще більшого письменника Шекспіра називав за його Араматичні заходи, як звісно, Аикарем» [18, с. 3]; не «Аикар» тут, звісно, Аивує, а система вимірювання - «великий», «більший»). 
У вимірі, запропонованому ще на початку XX століття М. Карєєвим, можна сказати, що культові факти, медійні скандали і еталонні фбакти належать до культурної історії. «Прагматичною історією, - писав він, -я називаю історію, котра досліджує події, на відміну від культурної, котра досліджує побут» [8, с. 7]; «поділяючи історичні фбакти на культурні і прагматичні або, що одне й те саме, на стани і подї, ми повинні, безперечно, віАносити соціальні антагонізми, як відомі настрої, до першої категорії, а всі випадки боротьби соціацьних сиц, як активні виступи, тобто Аії, - Ао Аругої» [8, с. 208]; «те, що АюАи роблять, це ми називаємо прагматикою, як вони це роблять - культурою» [8, с. 249]. Перші - короткі, миттєві - намежать зАебільшого історії мистецтва у їі найтрадиційнішому вимірі, тоді як інші, розгорнуті у часі, належать історії культури (музичної, театральної, візуальної) і культурології.

Мистецький винахіА, як пропозиція нового інструменту, способу, форми, функції, не зав-

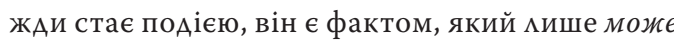
перетворитися на подію, тобто є потенційною подією або, за Станіславським, дійовим конбліктним бактом. Поглибленню впливу подібних фактів сприяє поширення творчості тих або інших авторів, моделей, жанрів тощо. Саме таку роль дуже часто відіграють постановки творів світової драматургії; байдуже, кого саме $з$ культових постатей буде обрано Аля цієї мети - Шекспіра або Макдонаха; у будь-якому разі цей факт означатиме Аолучення Ао чужого культу, прийняття чужої віри, отже, свіАчення власної меншовартості. Так само після Мацевича може бути створено незАіченну кількість квадратів найрізноманітніших кольорів, однак усі вони сприятимуть мише посиленню і розширенню культу винахіАника, а не наслідувачів у межах колоніального Аискурсу. Це означає також, що оголошення Шекспіра, як і будького іншого, найвидатнішим Араматургом світу свідчить про те, що й нас таки вихрестими і ми - нарешті! - стали новонаверненими в оАному з найпотужніших зі створених Британською імперією культів; нарешті нас прийняли до фбан-клубу Шекспіра або іншого з найвидатніших світових генїв! УсвіАомивши це, можииво, з більшим розумінням поставимося Ао постколоніацьної історії, праць ЕАварАа СаїАа, критичним погАяАом поАивимося на «шекспірівський канон» Гаролда Блума, згадаємо кардинала Ришельє з його іАеєю об'єАнаної Європи і перестанемо микуватися постановкою «ефіопської» гіпподрами про гетьмана Мазепу в амфітеатрі Естслея. Можииво, навіть замислимося про різницю між монологом і Аiалогом різних культур, а то й знову переконаємося у тому, що театральні Аіячі подеколи Аавали історикам гарні поради: «Короля грає оточення», - Ауже влучно сформулював Вахтангов. Так само, як у ролі оточення «граємо» Шекспіра і Макдонаха.

Попри те, що у політичній історії поАієва (наративна) історія давно сприймається як «учорашній Аень», мистецтвознавство Аосі не має подієвої історії, принаймні недостатньо артикукює їі. ААже подієва історія - це не канцюг пов'язаних між собою Аат, яскравих постатей (геніїв), творів (сенсацій, еталонів, реліквій) і більш або менш перекониивих коментарів стосовно їхнього «історичного значення»; це боАай орієнтовний канцюг подій, котрі змінияи мистецьке життя, художню культуру, статус $i$ мову мистеитва не «з історичної перспективи», а саме у конкретному історичному часі. BiAтак, за відсутності подієвої історії, однією з їі імітацій стає історія сенсаційна («ЗАебільшого історії археології, написані у XX столітті, коментує цей термін $\Lambda$ ев Кмейн, - були попуАярними книгами, завданням їх було розважити читача, отже, вони піАкреслюваци романтику археологічних розкопок і віАкриттів. ВіАповіАно, вони концентрували увагу на видатних археологах і найяскравіших, сенсаційних віАкриттях» $[9$, с. 16]). Це історія, сконцентрована на визнаних видатних постатях, їхніх твоpax і сенсаційних подіях. 
На відміну віА сенсаційної, подієва історія розкриває зміст минулого у процесі його змін крізь призму революційних подій (вибухів), винаходів і відкриттів. Приміром, можна Аовго розводитися про «світове значення» Шекспіра, однак історія не залишила жодного свідчення про те, що він і справді мав бодай якесь значення ААя Аоби, в якій жив і працював, що якимось чином уплинув на розвиток тогочасного театру. Те саме можна сказати і про інших «видатних діячів» та їхні «визначні твори» в історії сценічного, та й не тільки, мистецтва. Натомість зАоровий глузА Аає неспростовні піАказки з привоАу «видатних» поАій у царині політики, законодавства, технології, котрі визначили поАальший розвиток театральної культури: впровадження в античному театрі спочатку Аругого, а згодом і третього актора; Аозвіц на показ комедії піА час міських Аіонісій в афінському театрі; перехіА театру з площі Ао закритого приміщення (Аавньоримська вілма, мітургійна Арама, приАворний театр і т. ін.), що, у свою чергу, вплинуло на естетику театру (впроваАження антрактів та ін.); впровадження штанкетної системи; вигнання глядачів зі сцени у французькому театрі XVIII ст.; кодифікація амплуа у московському декреті Наполеона; упровадження у театрі газового, а згодом і електричного освітмення; Аемонополізація театру у Аругій половині XIX ст. у більшості країн Європи; впроваАження поворотного круга; становцення конкурента театру - кіномистецтва і запозичення у нього як композиційних (монтаж, наплив), так і технічних прийомів; одержавлення театру у багатьох країнах і т. ін.

Аналіз цих фактів показує, що головні подіi в історії мистецтва відбуваються зАебільшого не на сцені, а між сценою $і$ глядачем або ж навіть у самому соціумі - у його законодавчій, економічній, технічній, політичній та інших сферах. ЗАебільшого саме ці події визначали зміну мови мистецтва та його жанрової системи. Приміром, успіх українського театру корифеїв зумовлено не мише талантом його творців, а й урядовими заборонами, що передували його появі - Вацуєвським циркуляром (1863) та Емським указом (1876), котрі розбудими і сереА гляАачів, і серед театральних діячів енергію спротиву («наелектризована громада своїм ентузіазмом виявцяла не тільки вАячність артистам за їх виконання нехитрої п'єси, а в їх особі виявляла своє безмірне кохання Ао всього свого ріАного - українського, раділа віАродженню того, що Аосі було заборонено, загнано, заглушено московським безголовим урядом» [5, с. 214]). І ці події махи більше значення, ніж постановка на сцені найвидатнішої з видатних вистав. Так само і заборона театру пуританами мала більше значення Аля сценічного мистецтва, ніж котрась із вистав за творами Шекспіра. Так само й успіх театру Курбаса: зумовлений зміною поколінь, а також політичних і регіональних еліт, передусім саме внаслідок цього він викликав зміну естетичних орієнтирів. На відміну віА кмасичної Араматургії, канони якої вимагають оАнієї поАії Аля певного віАрізку часу, зміни у театральній культурі залежать віА багатьох поАій, котрі можуть віАбуватися оАночасно у різних площинах - політичній, економічній тощо. I «естетична вартість» вистави не розпочинає цей поАієвий ряА, а за-

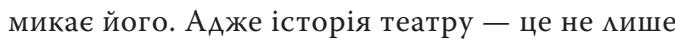
естетичний коментар Ао хроніки театрацьного життя, передусім це історія театрацьного бізнесу, в якому «естетичний» чинник, поряА із іАеологією, політикою, конкуренцією з іншими виАами мистецтва, моАою тощо виступає Аише однією зі складових виробництва творів мистецтва. ОАнак саме подія дозволяє виявити, як на тих або інших етапах історії на перше місце виходить то іАеологічний, то технологічний, то естетичний елемент. Хоча, безперечно, між ними існує зв'язок - так, на межі XVIXVII століть ми помічаємо Ауже високу щільність поАій: спочатку соціацьні мотиви (геАонізм i «Аемонстративне споживання») запроторюють приАворний театр у закрите приміщення; внаслідок цього (зміна простору і технології) 
ААя освітлення починають використовуватися свічки; це змушує постановників запроваджувати антракти, а гонитва за збімьшенням естетичних подразників - поява у кожному акті нової Аекорації - вимагає збімьшення тривамості антрактів і появи інтермедій (зміна композиції вистави). Тут, звісно, можна Аовго розводитися про те, наскільки внаскіАок цих технологічних змін збільшувалася (або зменшувалася) художня вартість, однак це не має значення, аАже рушієм тогочасного сюжету стає новий мистецький винахіА - придворний театр, що й провокує новий процес - намагання вгамувати спрагу за все потужнішим чуттєвим подразником; звісно, у контексті «демонстративного споживання».

Перш ніж розглядати з точки зору подієвої історії відомі історичні фбакти і намагатися їх кваліфікувати, уточнимо кмючове, принаймні Аля сценічного мистецтва, поняття подіï. Це завершений вчинок персонажа, котрий призвів Ао зміни запропонованих обставин, вкцючаючи зміну стосунків між персонажами і т. ін. Приміром, випадково (перипетія) скоєний Ромео кримінальний злочин - убивство Тибальта в «Ромео і Ажульєтті» В. Шекспіра -

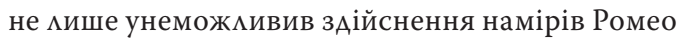
i Ажумьєтти, а й перетворив Ромео на змочинця, що позбавицо сімейство Монтеккі нащаАка i, таким чином, створицо умови Аля остаточного перерозподіку влаАи у Вероні на користь сімейства Капулетті. Залежно віА трактування, фінахьну подію (смерть закоханих) може бути визначено або як революційну (якщо після смерті закоханих у Вероні було припинено ворожнечу і встанов ено мир), як безпміАний бунт (якщо самогубство Ромео і Ажульєтти істотно нічого не змінило і не мало наслідків) або як смерть міста (аАже вся молодь цієї п'єси, котра мусима би продовжувати ріА Монтеккі і Капулетті, загинула). На віАміну віА подій, важмиві фак$m u$ - знайомство Ромео і Ажумьєтти піА час балу, нічне побачення піА балконом і навіть та-

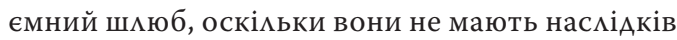

для всіх персонажів n'єси, - не належать до вибухів, подій ревомюційного характеру, аАже нічого не змінюють у житті Верони. ОАна з особливостей поАій у «Ромео і Ажумьєтті» - випаАковий, всупереч нормативній теорії драми, характер: випадково Ромео познайомився 3 Ажульєттою, за збігом обставин закохані виявимися Аітьми ворогуючих сімей і т. ін. Причому всі ці випадки могми Аягти і в основу комеAiї: батьки чинять спротив Аітям, котрі мають намір побратися, і тоді на Аопомогу їм прихоАить якийсь скуга Авох панів - Скапен, а в Шекспіра - Аоренцо, який пропонує закоханим хитромуару інтригу. Якби не фатальний випаАок - убивство Тибальта, п'єса мусима би завершитися весімлям. ОАнак випадок втручається і Аамі - вісник запізнюється через чуму, Ромео не Аізнається про Аеталі плану, внаслідок чого чинить самогубство. Так само вирішальну ромь випаАку спостерігаємо й у «Гамлеті». Якби Гамлет випадково не вбив Помонія, а вбив Кмавдія, як планувацося, сюжет було би вичерпано. Інша справа, що, скажімо, у «Ромео і Ажумьєтті» перелічені події ми можемо сприймати як закономірний результат пристрастей, що вирують піА час чуми (ця метафорична обстави-

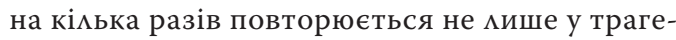
Аї̈ Шекспіра).

В чому ж полягає найголовніша віАмінність між фактами, усіма їхніми різновидами і подіями? Аише у статусі - у статусі факту, отриманого ним у конкретних запропонованих обставинах («Те, що є подією, фактом, $є$ існуванням станів речей» [6, с. 24]). В оАних обставинах він так і замишається елементарним (неподільним), ніким не поміченим фактом, тоді як в інших перетворюється на медійний бакт, атракціон або головну подію. Різницю між фактами і поАіями зумов ено територією, на яку вони зАатні впливати. Мало хто переАбачав, Ао яких наслідків призвеАуть вибори 1933 року Ао Райхстагу. Ті, що змогли розпізнати у цьому факті ознаки події, наступного ж Аня зацишили країну.

ПіАступність визначення головної подї̈ тому, 
що, подивившись на неї з іншого боку, ми перестанемо сприймати її як головну. Хтось визначить головні події інакше, але кмючові обставини (факти) - ні. Ава найголовніших фбакти, без яких трагеАія «Ромео і Ажульєтта» не віАбудеться, - ворожнеча і кохання (про кохання тут поки що Аоволі абстрактно, аАже поняття надто Аинамічне і хитке). Ворожнеча - бакm культурний (звичаєвий), тоАі як кохання - «приватна ініціатива», суб'єктивний чинник, який вступає у конфлікт з культурою. Або інакше кохання, як і ворожнеча, народжується внасліАок незагнузданих пристрастей. Ще більше піАстав Аля сумніву у значенні головної події дає «Аон Жуан» Мольєра, де взагалі немає жодної події, що об'єАнувала 6 усіх персонажів твору. Натомість існують фбакти, без яких п'єса не відбудеться. Це мінія стосунків Аон Жуана з Командором - віА запрошення на вечерю Ао самої вечері.

Із наведених прикладів зрозуміло, що різні Аослідники, навіть однаково визначаючи місце того або іншого ффакту (подіï) в історії мистецтва, можуть Аавати факту (події) різні імена, тим самим пропонуватимуть різні його інтерпретації: навіть, зАавалося б, нейтральне визначення факту «перша вистава в Афінах» свідчить про невизнання АосліАниками Аодержавного етапу театрального мистецтва. Формула «перша вистава в Афінах» вказує на те, що йдеться не про мистецький винахіА, а про «одержавлення / привласнення Аержавою» театру, «створення першої потужної пропагандистської машини» і т. ін. Таку саму подію одержавцення з усіма її здобутками (дотація) і втратами (втрата самостійності) було зАійснено і в Україні, що Аозволико зАійснити віАому "рокіровку», "устоличнення», внаслідок якого театр Курбаса було переведено Ао тодішньої політичної столиці, а Гната Юру заслано Ао «провінції». Отже, подія невіААімьна віА її назви, бо незначна, зАавалося 6, відмінність у назві насправAi описує іншу подію: «Писати “населення" замість “народ” і “землеволодіння" замість “зем-
$\Lambda я "$ в наш час уже само по собі означає в багатьох випадках відмову віА неправди, очищення цих понять віА містичного кушпиння» [3, с. 75].

ГАибинні зміни зазвичай відбуваються не в результаті запозичення мистецьких форм, а в результаті неусвідомленої, медь помітної зміни статусу мистецтва. Приміром, значну частину конфміктів радянських митців із системою було зумовлено саме зіткненням різних статусів митця: романтичного генія в уяві самого митця, гасма «свободи творчості» у пропаганАі і «гвинтика» у партійній доктрині. А це означає, зокрема, що історичний аналіз мистецьких явищ минумого поза з'ясуванням статусу мистецтва саме у минулому - позбавлено сенсу. Інша справа зіставцення статусу мистецького явища у своєму історичному часі і у часі досліАника. Звісно, статус визначається не кише епітетами, переАусім - Аією: офіційний статус - віАвіАанням вистав або виставок першими особами держави, АисиАентський - заборонами, арештами, бульдозерами (як тут не згадати репліку Анни Ахматової після суду наА Бродським: «Какую биограбию делают нашему рыжему! Как будто он кого-то нарочно нанял»).

Факти, котрі не перетворикися на події, мають не менше значення, ніж події, тільки в іншій історії - в історії, в якій головна роль намежить сукупності елементарних оАиничних (неподільних, атомарних) фактів, незалежно віА того, оАноріАні вони чи неоАноріАні. Ао таких фбактів, назвемо їх фабульними, у трагеАіï «Ромео і Ажульєтта» належать і бійка слуг, і перше побачення закоханих, і таємний шлюб Ромео і Ажульєтти. ОАнак в основі сюжету межатиме явище - брутальна пристрасть, котра $\epsilon$ і рушієм ворожнечі, i, так само, юнацького кохання. Об'єАнуючи емементарні, оАиничні фбакти, дослідник утворює нові - факти, приховані від очей, бакти неочевидні, ті, заради яких зАебільшого і зАійснювакася подорож, - факти культурної історіі.

Факти культурної історії узагальнюють менші, елементарні фбакти. ОАиничний фбакт - 
перший показ 534 р. Ао Р. Х. трагеАї̈ в Афінах, піА час свята Великих Аіонісій - стає першим сереА інших, які сукупно, залежно віА точки віАціку, можемо інтерпретувати як явище привласнення трагедї державою, як початок становлення театральної культури в Афінах, і навіть визначити одну з особливостей тодішньої театрацьної кумьтури, а саме - ï̈ залежність і формування у політичній і релігійній площині. Інша сукупність фактів - Ао 20 тисяч глядачів, заохочення владою відвідування вистав простолюдом (теорикони), часткове покриття витрат на вистави з державної скарбниці (або ненадходження до неї податків, спрямованих хорегами на постановку вистав), увічнення пам'яті переможців у драматичних змаганнях й опора на оАин із наймасовіших культів (Аіонісії - свято виноробів) свідчить, що показ трагеАій був масовим релігійно-політичним Аійством. Так само про політичну волю влаАних кіл свідчить аналіз дидаскалій, аАже канонізація Есхіла, Софокма й ЕврипіАа не підкріплюється кількістю отриманих ними перемог піА час Араматичних змагань. Чомусь в істо-

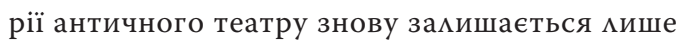
троє трагеАіографів, немов укотре вже АовоАячи, що число це - магічне.

Розглядаючи «театр як засіб виробництва» [2, с. 63], мусимо погодитися із тим, що й історія театру 一 це також засіб виробництва, засіб виробництва пам'яті. Тому, «ви- робцяючи пам'ять», «говорімо краще про приватнов асницькі віАносини» $[4$, с. 93] і про те, що в усі часи різні сили, як би ми їх не назива$\Lambda$ и (у комуністичному мексиконі вони називаАися «прогресивними» і «реакційними»), прагнули і прагнуть приватизувати виробництво пам'яті. Найпершою ознакою приватизації стає натхненне якимись (звісно, прогресивними) іАеями впроваАження з позиції сили мови ворожнечі, зокрема й аАресованої своєму минумому. А це змушує поставити питання про те, чи прагнемо ми мати спікьну пам'ять, і чи мож$\Lambda$ ива спільна пам'ять взагалі, чи не $\epsilon$ вона неАосяжним іАеалом? Якщо в історії мистец-

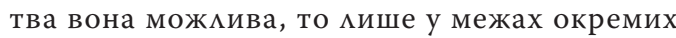
сегментів, рубрик, фактів, аАже наАто залежна віА особистих смаків, власного життєвого АосвіАу, тобто віА усього того комплексу, який можна охарактеризувати поняттям cnoстерігач, навіть якщо він щиро прагне бути об'єктивним.

Висновки. Розглянуто, Аиференційовано і запропоновано способи використання основних понять подієвої історії мистецтва: свідчення факт - подія - явище - реліквія - рубрика та ін. На численних прикцадах з історії світового й українського театру продемонстровано плідність подієвої історії мистецтва як потужного інструменту деміфологізації історії і можАивості застосування Аійового аналізу у процесі дослідження історії мистецтва.

\section{$\Lambda$ ітература}

1. Барг М. Категории и методы исторической науки. Москва: Наука, 1984. 342 с.

2. Брехт Б. Аиалектическая Араматургия // Театр: Пьесы. Статьи. Высказывания: В 5 т. Москва: Искусство, 1965. С. 51-64.

3. Брехт Б. Пять трудностей пишущего правду // Театр: Пьесы. Статьи. Высказывания: В 5 т. Москва: Искусство, 1965. С. 66-81.

4. Брехт Б. Речь на первом международном конгрессе писателей в защиту культуры (Париж, 1935) //

Театр: Пьесы. Статьи. Высказывания: В 5 т. Москва : Искусство, 1965. С. 88-93.

5. Ванченко К. Спогади українського мицеАія // Червоний шлях. 1928. № 7. С. 213-231.

6. Вітгенштайн $\Lambda$. Tractatus logico-filosoficus. Фікософські дослідження. Київ: Основи, 1995. 311 с. 
7. Ершов П. Режиссура как практическая психология: Взаимодействие мюдей в жизни и на сцене. Москва: Искусство, 1972. 352 с.

8. Кареев Н. Историология: Теория исторического процесса. Москва: АИБРИКОМ, 2011. 328 с.

9. Клейн А. История археологический мысли. В 2 т. Т. 1. СПб.: ИзА-во С.-Петерб. ун-та, 2011. 688 с.

10. Кнебель М. О том, что мне кажется особенно важным. Москва: Искусство, 1971. 520 с.

11. Кнебель М. Поэзия педагогики. Москва: ВТО, 1976. 526 с.

12. Кнебель М. Слово в творчестве актера. 3-е изА. испр. Москва: ВТО, 1970. 160 с.

13. Колінгвуд Р. Аж. ІАея історії. Київ: Основи, 1996. 615 с.

14. Леман Х. Т. Постараматический театр. Москва: ABCdesign, 2013. 312 с.

15. Лотман Ю. Культура и взрыв. Семиосфера. СПб.: Искусство, 2000. С. 12-149.

16. Мамонтов Я. Араматургія І. Тобілевича. Твори. Т. 6: Біографія. Бібліографія. Критика. Архівні матеріали. Харків, 1931. С. 143-251.

17. Станиславский К. «Горе от ума» А. С. Грибоедова. Собрание сочинений: В 9 т. Т. 4: Работа актера наА ролью: Материалы к книге. Москва: Искусство, 1991. С. 48-173.

18. Стешенко I. Історія української Арами. Київ, 1908. 309 с.

19. Товстоногов Г. А. Чехов «Три сестры». Репетиции спектакмя 12 октября 1964 года - 23 января 1965 года. Круг мыслей: Статьи. Режиссерские комментарии. Записи репетиций. Аенинград: Искусство, 1972. С. 171-223.

20. Уайm X. Метаистория. Историческое воображение в Европе XIX века. Екатеринбург: ИзА-во Урал. ун-та, 2002. 528 с.

\section{References}

1. Barg M. Kategorii i metodyi istoricheskoy nauki. Moskva: Nauka, 1984. 342 s.

2. Breht B. Dialekticheskaya dramaturgiya // Teatr: Pesyi. Stati. Vyiskazyivaniya: V 5 t. Moskva: Iskusstvo, 1965. S. 51-64.

3. Breht B. Pyat trudnostey pishuschego pravdu // Teatr: Pesyi. Stati. Vyiskazyivaniya: V 5 t. Moskva: Iskusstvo, 1965. S. 66-81.

4. Breht B. Rech na pervom mezhdunarodnom kongresse pisateley v zaschitu kulturyi (Parizh, 1935) // Teatr: Pesyi. Stati. Vyiskazyivaniya: V 5 t. Moskva : Iskusstvo, 1965. S. 88-93.

5. Vanchenko K. Spogady` ukrayins`kogo ly`cediya // Chervony`j shlyax. 1928. \# 7. S. 213-231.

6. Vitg`enshtajn L. Tractatus logico-filosoficus. Filosofs`ki doslidzhennya. Ky`yiv: Osnovy`, 1995. 311 s.

7. Ershov P. Rezhissura kak prakticheskaya psihologiya: Vzaimodeystvie lyudey v zhizni i na stsene. Moskva: Iskusstvo, 1972. $352 \mathrm{~s}$.

8. Kareev N. Istoriologiya: Teoriya istoricheskogo protsessa. Moskva: LIBRIKOM, 2011. $328 \mathrm{s.}$

9. Kleyn L. Istoriya arheologicheskiy myisli. V 2 t. T. 1. SPb.: Izd-vo S.-Peterb. un-ta, 2011. $688 \mathrm{s.}$

10. Knebel M. O tom, chto mne kazhetsya osobenno vazhnyim. Moskva: Iskusstvo, 1971. $520 \mathrm{~s}$.

11. Knebel M. Poeziya pedagogiki. Moskva: VTO, 1976. 526 s.

12. Knebel M. Slovo v tvorchestve aktera. 3-e izd. ispr. Moskva: VTO, 1970. 160 s.

13. Kolingvud R. Dzh. Ideya istoriyi. Ky`yiv: Osnovy`, 1996. 615 s.

14. Leman H. T. Postdramaticheskiy teatr. Moskva: ABCdesign, 2013. $312 \mathrm{s.}$

15. Lotman Yu. Kultura i vzryiv. Semiosfera. SPb.: Iskusstvo, 2000. S. 12-149.

16. Mamontov Ya. DramaturgIya I. TobIlevicha. Tvori. T. 6: BIograflya. BIbllograflya. Kritika. ArhIvnI materIali. HarkIv, 1931. S. 143-251.

17. Stanislavskiy K. «Gore ot uma» A. S. Griboedova. Sobranie sochineniy: V 9 t. T. 4: Rabota aktera nad rolyu: Materialyi k knige. Moskva: Iskusstvo, 1991. S. 48-173. 
18. Steshenko I. Istoriya ukrayins`koyi dramy`. Ky`yiv, 1908. 309 s.

19. Tovstonogov G. A. Chehov «Tri sestryi». Repetitsii spektaklya 12 oktyabrya 1964 goda - 23 yanvarya 1965 goda. Krug myisley: Stati. Rezhisserskie kommentarii. Zapisi repetitsiy. Leningrad: Iskusstvo, 1972. S. 171-223.

20. Uayt H. Metaistoriya. Istoricheskoe voobrazhenie v Evrope HIH veka. Ekaterinburg: Izd-vo Ural. un-ta, $2002.528 \mathrm{~s}$.

\section{Клековкин А. Ю. Событие в истории искусства: производство статуса}

Аннотация. Общая история, история исполнительского искусства, как и театральная режиссура, сходятся в одной из своих заАач: созАании истории (придуманной ики правдивой), события среАствами своей науки или искусства, с опорой на исторические источники у ученых или на текст драмы - у режиссера. Это означает, что исследовательские методы общей истории, как и методы режиссерского анализа, могут быть заимствованы историей перформативного искусства, тем более что кмючевые понятия, на которые опираются названые отрасли - факт и событие - совпадают. В дискуссиях по поводу природы научного факта можно выделить несколько главных подходов, среди которых: факт - это сообщение какого-то источника, свидетеля и т. п.; факт - это то, что произошло на самом деле; научный факт - это конструкт, созданный исследователем в результате анализа, сопоставления и обобщения единичных элементарных фактов, следов какого-то события. Еще больше разногласий существует в определении понятия «событие». НеАостаточная четкость в опреАелении этих и Аругих связанных с ними понятий приводит иногда к бессознательной манипуляции - подмене фактов историческими свидетельствами, событий - фактами, в частности фактами культовыми, медийными, что приводит, в конце концов, к Аоминированию в истории искусства субъективного, религиозного или идеологического фактора. На многочисленных примерах из истории мирового и украинского театра обнаружены образцы истории, написанной вопреки фактам (когАа игнорирование различий между показаниями и разАичными статусами факта - факт, событие, реликвия, прецедент т. А. - приводит к созданию исторических мифов, господство которых обусловлено, в частности, имперскими вАияниями) и продемонстрированы возможности применения метода действенного анализа в истории театра. Рассмотрение истории перформативного искусства с точки зрения событийной истории созАает преАпосылки Аля изменения повестки Аня и расширение рубрик - перечня вопросов, ответы на которые должны обогатить не только искусствоведение, но и художественную практику, знания не только о прошлом театра, но и о его современном состоянии.

Ключевые слова: Факт - статус факта (элементарный, медийный, скрытый, прагматичный, культурный) - событие - явмение - реликвия.

\section{Klekovkin $O$. Y. Event in the history of art: status production}

Abstract. The general history, the history of performing arts, as well as theatrical directing, coincide in one of their tasks: the creation of a story (fictitious or true), the production of events by means of their science or art, based on historical sources from scholars or on the text of drama - by the director. Consequently, the general history research methods, as well as methods of directorial analysis of drama, can be borrowed by the performing arts history, especially considering that the key notions, on which the mentioned branches are based - the fact and the event - are coincide. In discussions about the nature of the scientific fact, it is possible to distinguish several main approaches, among which: the fact is the message of a source, a witness, etc., fact is what actually happened; scientific fact is a construct created by the researcher as a result of analysis, comparison and generalization of individual elementary facts, traces of an event. Much more discrepancies exist in defining the notion of event. Insufficient clarity in the definition of these and some other related concepts leads to unconscious substitution: of the facts - by historical evidence, of events - by facts, in particular the cult, media facts, which, in the end, creates favorable opportunities for domination of subjective, religious, ideological, but in fact - speculative factor, in the history of art. Providing numerous examples from the world and Ukrainian theater history, the author discovers instances of "history, written contrary to the facts" (when ignoring the differences between testimonies, facts and events leads to the creation of historical myths, the domination of which is caused by imperial influences, in particular) and demonstrates the possibility of applying an active analysis in the theatre history. Consideration of the performing arts history from the perspective of the event history creates the prerequisites for changing the agenda and the expansion of the headings - a list of questions, the answers to which must enrich not only artistic knowledge, but also artistic practice, knowledge not only about the past of the theater, but also about its current state.

Keywords: The fact - status fact (elemental, media, hidden, pragmatic, cultural) - an event - a phenomenon - a relic. 